\title{
Microalgae population dynamics in photobioreactors with secondary sewage effluent as culture medium
}

\author{
Adriano E. Marchello ${ }^{1}$, Ana T. Lombardi ${ }^{2}$, Maria José Dellamano-Oliveira ${ }^{2}$, \\ Clovis W.O. de Souza ${ }^{3}$ \\ ${ }^{1}$ Departamento de Hidrobiologia, Universidade Federal de Sao Carlos, São Carlos, SP, Brazil. \\ ${ }^{2}$ Departamento de Botânica, Universidade Federal de Sao Carlos, São Carlos, SP, Brazil. \\ ${ }^{3}$ Departamento de Morfologia e Patologia, Universidade Federal de Sao Carlos, São Carlos, SP, Brazil.
}

Submitted: November 18, 2013; Approved: June 6, 2014.

\begin{abstract}
Nitrogen and phosphorus present in sewage can be used for microalgae growth, possibiliting cost reduction in the production of microalgae at the same time that it decreases the eutrophication potential of the effluent. This research aimed at monitoring the native community of microalgae and coliform bacteria in a secondary effluent from anaerobic municipal sewage treatment. Two treatments (aerated and non-aerated) were performed to grow microalgae under semi-controlled conditions in semiclosed photobioreactors in a greenhouse. The results showed no significant $\mathrm{pH}$ and coliforms (total and Escherichia coli) variation between treatments. Nutrient concentrations were reduced supporting microalgae growth up to $10^{7}$ cells. $\mathrm{mL}^{-1}$ independent of aeration. Exponential growth was obtained from the first day for the non-aerated, but a 5 day lag phase of growth was obtained for the aerated. Chlorella vulgaris was the dominant microalgae (99.9\%) in both treatments. In the aerated, 5 algae classes were detected (Chlorophyceae, Cyanophyceae, Chrysophyceae, Bacillariophyceae and Euglenophyceae), with 12 taxa, whereas in the non-aerated, 2 classes were identified (Chlorophyceae and Cyanophyceae), with 5 taxa. We concluded that effluent is viable for microalgae growth, especially Chlorella vulgaris, at the same time that the eutrophication potential and coliforms are decreased, contributing for better quality of the final effluent.
\end{abstract}

Key words: microalgae, effluent treatment, coliforms, Escherichia coli, Chlorella vulgaris.

\section{Introduction}

Secondary effluents generated from anaerobic treatment of domestic sewage are commonly disposed of in water bodies although they may not have ecologically acceptable physical, chemical and/or biological composition. Most often they contain organic matter, nutrients, metals and pathogens, leading to the pollution and contamination of aquatic environments (Zanetti et al., 2006). Usually, the continuous discharge of such effluents is a cause of accelerated eutrophication. Thus, there is a need for tertiary treatments to further reduce nutrients concentration and pollution potential of secondary sewage effluents.

According to Hammouda et al. (1995), Villaverde (2004) and Weismann et al. (2007), anaerobic sewage treatment does not remove efficiently nitrogen $(\mathrm{N})$ and phosphorus $(\mathrm{P})$, remaining available for the phytoplankton community. Released into the environment, this can support microalgae growth, leading to excessive biomass increase that will end up, decomposed by heterotrophic microorganisms, causing oxygen deficit, and all the other negative effects of eutrophication such as the death of aquatic animals (Oswald, 1988; Olguín, 2003). The mean concentration of $\mathrm{N}\left(40 \mathrm{mg} . \mathrm{L}^{-1}\right)$ and $\mathrm{P}\left(8 \mathrm{mg} . \mathrm{L}^{-1}\right)$ per liter of effluent is sufficient to produce $0.6 \mathrm{~g}$ of microalgae with a productivity of 77,600,000 kg.day ${ }^{-1}$ (Klausmeier et al., 2004). The N:P ratio ideal for microalgae growth according to the Redfield ratio is around $16: 1$, representing an average ratio, that can vary among species, from 8:1 to $45: 1$ (Klaus-

Send correspondence to A.E. Marchello. Departamento de Hidrobiologia, Universidade Federal de Sao Carlos, Rodovia Washington Luiz km 235, 13565-905 Sao Carlos, SP, Brazil. E-mail: dri_marchello@hotmail.com. 
meier et al., 2004; Christenson and Sims, 2011; PerezGarcia et al., 2011).

Growing microalgae in such effluents has several advantages, besides reducing the eutrophication potential and the number of bacteria in the effluent (de La Noüe et al., 1992; Hammouda et al., 1995; Hoffmann, 1998). According to Oswald (1998), de Bashan et al. (2004) and Shantala et al. (2009), heterotrophic bacteria in the effluent will decompose biodegradable organic matter, produce carbon dioxide, ammonium, nitrates and phosphates for microalgae use (Olguín, 2003). Through photosynthesis, microalgae produce oxygen, supporting the degradation of organic matter and reduction of the biochemical oxygen demand in the effluent by aerobic bacteria. Also, the oxygen and $\mathrm{pH}$ variation induced by microalgae photosynthesis help reduce coliform and other pathogenic bacteria in the effluent (Pearson, 1986; Oswald, 1988; Mayo and Noike, 1994; Meiring et al., 1994; Davies-Colley et al., 1997; Aksu 1998; Metcalf and Eddy, 2003; Kiso et al., 2005).

According von Sperling (1996), some algal groups dominate over others depending on the physical (solids, turbidity, absorbance, temperature, electrical conductivity), chemical ( $\mathrm{pH}$, chloride, alkalinity, nitrogen, phosphorus, gases, metals, organic compounds, among others) and biological (bacteria, funghi, virus, protozoans, larvae) features of the effluent (von Sperling, 1996; Metcalf and Eddy, 2003). The genera most commonly found in effluents from wastewater treatment plants (WWTPs) are: Chlorella, Scenedesmus, Chlamydomonas, Micractinium, Euglena, Ankistrodesmus, Oscillatoria, Microcystis, Nitzchia, Navicula and Stigeoclonium (Palmer, 1969; Mara and Pearson, 1998; Amengual-Morro et al., 2012).

Commercial production of microalgae is expensive, and the addition of nutrients in culture media contributes to its high cost. Therefore, the growth of microalgae in wastewater effluents can be a way to reduce algal cultures costs. Biofertilizers and biofuel do not require high purity cultures as required for applications of microalgae in pharmaceutical or food industry (Mayo and Noike, 1994; Cho et al., 2011), so wastewater effluents may suffice for such algae production. Understanding the behavior and growth of indigenous microalgae in the effluent over time is important to define the suitability of the effluent and algae growth conditions for biotechnological interest focusing on a large scale algal production system (Oswald, 1988).

This study investigated the composition of indigenous phytoplankton present in a secondary effluent from anaerobic sewage treatment that collects and treats altogether the sewage from an aircroft maintanance stablishmens and domestic sewage. Microalgae growth reduction of nutrients ( $\mathrm{N}$ and $\mathrm{P}$ ), as well as the reduction of coliform bacteria (total and Escherichia coli). The potential of such secondary effluent from anaerobic sewage treatment for the production of algal biomass while reducing nutrients and coliform bacteria concentrations are discussed.

\section{Materials and Methods}

\section{Samples and experimental conditions}

Secondary effluent $(50 \mathrm{~L})$ from anaerobic treatment whose sewage is originated from domestic and aircraft maintenance stablisiment was obtained before its discharge into the receiving water body at the wastewater treatment plant of Água Vermelha district (São Carlos, SP, Brazil). The wastewater treatment plant treat approximately $8 \mathrm{~L}$ of sewage per second from a population of approximately 3,500 people plus the residues from the aircraft maintenance stablishment.

The experiments consisted of eight bioreactors used in partially sealed system with $8 \mathrm{~L}$ capacity containing $5 \mathrm{~L}$ of the secondary sewage effluent each. The bioreactors consisted of transparent plastic cylindrical reservoirs, internally coated with transparent low density polyethylene bags that were covered with PVC film, measuring $26 \mathrm{~cm}$ high by $27 \mathrm{~cm}$ diameter. Of these, 4 bioreactors received artificial aeration through air pump (Regent Air Pump, Model 8500), refereed as aerated treatment and 4 were left without aeration (non-aerated treatment). Thus, treatments were performed with 4 experimental replicates. Samples for the determination of the initial conditions of the effluent were obtained immediately after arrival of the effluent in the laboratory and before incubation. The photobioreactors were incubated during 30 days in a greenhouse at the Botany Department, Federal University of São Carlos (Brazil). Temperature in the greenhouse varied from $23^{\circ} \mathrm{C}$ at night up to $30{ }^{\circ} \mathrm{C}$ at midday. Light intensity varied from $4.6 \mu \mathrm{mol} \cdot \mathrm{m}^{-2} . \mathrm{s}^{-1}$ at $8: 00 \mathrm{~h}$ to a maximum of $37 \mu \mathrm{mol} \cdot \mathrm{m}^{-2} \cdot \mathrm{s}^{-1}$ at noon (12:00) with natural sunlight photoperiod during 30 days between autumn 2012. In this time of year, the climate in sub-tropical weather has the greater thermic oscilation of the year.

\section{$\mathrm{pH}$ and chlorophyll $\mathrm{a}$}

Bioreactors were monitored for $\mathrm{pH}$ (pHmeter pHep ${ }^{\circledR}$, Brazil) and chlorophyll $a$ concentration on alternative days. Chlorophyll $a$ was determined by in vivo fluorescence using a fluorimeter (Turner Designs, Model Trilogy U.S.A.) and its concentrations were obtained from a calibration curve performed through fluorescence intensity vs concentration of chlorophyll $a$ extracted from exponentially growing cultures of Chlorella sorokiniana.

\section{$\mathrm{N}$ and $\mathrm{P}$ concentrations}

Total nitrogen $(\mathrm{N})$ and phosphorus $(\mathrm{P})$, and dissolved nutrients (nitrate, nitrite, ammonium and phosphate) were determined according to APHA (2005) at the beginning and end of the experiment. For the determination of dissolved nutrients samples were first filtered through glass fiber filter $(3.0 \mu \mathrm{m}$ pore diameter $)$ and then through $0.45 \mu \mathrm{m}$ pore diameter cellulose acetate membrane (Sartorius). 


\section{Phytoplanktonic community}

Qualitative and quantitative analysis of the phytoplankton community were performed on samples collected every 5 days. All bioreactors, aerated and non-aerated, were homogenized manually before sampling. For the qualitative analysis samples were preserved in $4 \%$ formaldehyde solution and analyzed using a Zeiss light microscope with maximum magnification of 2560 times. Algae identification was made to the taxonomic level as detailed as possible by consulting specialized literature (Komárek and Fott, 1983; Anagnostidis and Komárek, 1989; Komárek and Anagnostidis, 1999; Bicudo and Menezes, 2005; Komárek and Anagnostidis, 2005). For the quantitative analysis, $90 \mathrm{~mL}$ sample was collected and preserved with Lugol's acid solution. Microalgae populations were counted under an inverted microscope (Zeiss, Axiovert 200), with 400x magnification using the method described in Utermöhl (1958). Depending on the concentration of organisms, samples ranging within 10 and $50 \mathrm{~mL}$ were allowed to settle for at least $3 \mathrm{~h}$ (Wetzel and Likens, 1991). Individuals (cells, colonies, filaments and/or coenobia) were counted in randomized fields and densities calculated according to APHA (2005), and expressed as cells. $\mathrm{mL}^{-1}$.

Total microalgae productivity $(\mathrm{P})$ in the bioreactors is reported as cell. $\mathrm{mL}^{-1}$.day ${ }^{-1}$ was obtained according to Eq. (1) as described below:

$\mathrm{P}=$ (final cell density - inicial cell density) / incubation time (days)

\section{Coliforms analyses}

Total coliforms and Escherichia coli samples were obtained from each biorreactor and quantified on alternate days until colonies were no longer detected. Samples (1 $\mathrm{mL}$ ) were diluted in phosphate buffered saline solution (PBS) to the decimal scale $10^{-3}$. Each dilution was inoculated in duplicates into sterile and disposable Petri dishes by the Pour Plate Method according to APHA (2005). For this, the culture medium Cromocult ${ }^{\circledR}$ Coliform Agar (Merck KGaA, Germany) was used. The Petri dishes were then incubated under controlled conditions at $36^{\circ} \mathrm{C}$ for $24 \mathrm{~h}$ in the dark. The colonies were counted and the results expressed as colony forming units per volume $\left(\mathrm{CFU} \cdot \mathrm{mL}^{-1}\right)$.

\section{Data analyses}

The results were analyzed using $t$-test to compare mean values obtained from the aerated and non-aerated treatments. For analysis of the results within each treatment ANOVA (Hammer et al., 2001) was used.

\section{Results}

\section{$\mathrm{pH}$ and chlorophyll $\mathrm{a}$}

Figure 1 reports $\mathrm{pH}$ values as function of time. It shows that $\mathrm{pH}$ was maintained within 8.5 and 9.5 up to the 18th incubation day and while algae were growing, after which microalgae growth decreased and so did the $\mathrm{pH}$, to near 6.0 at the end of the experiment $\left(30^{\text {th }}\right.$ day). No significant $\mathrm{pH}$ variations were observed between the aerated and non-aerated treatments ( $t$-test, $\mathrm{p}>0.05)$.

Microalgae growth, reported as chlorophyll a concentrations and cell. $\mathrm{mL}^{-1}$ as function of time are shown in Figure 2. It is observed that the aeration process resulted in an extended adaptation or lag growth phase in the first 5 days, possibly due to the modification of the conditions imposed by the air bubbling. In the non-aerated treatment, cells grew exponentially since the beginning of the experiment. According to equation 1 , the productivity (cells. $\mathrm{mL}^{-1} \mathrm{day}^{-1}$ ) was 3.4 times higher in the aerated $\left(2.4 \times 10^{5}\right.$ cells. $\mathrm{mL}^{-1}$. day $\left.{ }^{-1}\right)$ than in the non-aerated treatment $\left(7.1 \times 10^{4}\right.$ cells. $\mathrm{mL}^{-1}$.day ${ }^{-1}$ ) treatment. Although higher productivity was obtained for the aerated treatment, significant differences $(\mathrm{p}<0.05)$ for chlorophyll $a$ concentrations between the two treatments were obtained for the 5,25 and $30^{\text {th }}$ experimental days only.

\section{$\mathrm{N}$ and $\mathrm{P}$ concentrations}

Table 1 shows the concentration of nutrients in absolute and relative values for both aerated and non-aerated treatments. Higher nutrient reduction was obtained for the aerated in comparison with the non-aerated treatment.

\section{Phytoplanktonic community}

Taxonomic composition and relative abundance of each taxon detected in the experiments are presented in Tables 2 and 3 for the aerated and non-aerated treatment, respectively. Dominance was observed for the Chlorophyceae Chlorella vulgaris in both treatments. This species amounted more than $99 \%$ of the total algae biomass.

Other taxa belonging to the Chlorophyceae were also observed, but at lower densities. Chlamydomonas sp (1.8\%), Scenedesmus acuminatus (0.04\%), Oocystis sp (0.1\%), Desmodesmus quadricauda (0.33\%) and Desmodesmus sp $(0.01 \%)$. Cyanophyceae was present in approximately $36.6 \%$ of the total algae biomass, compris-

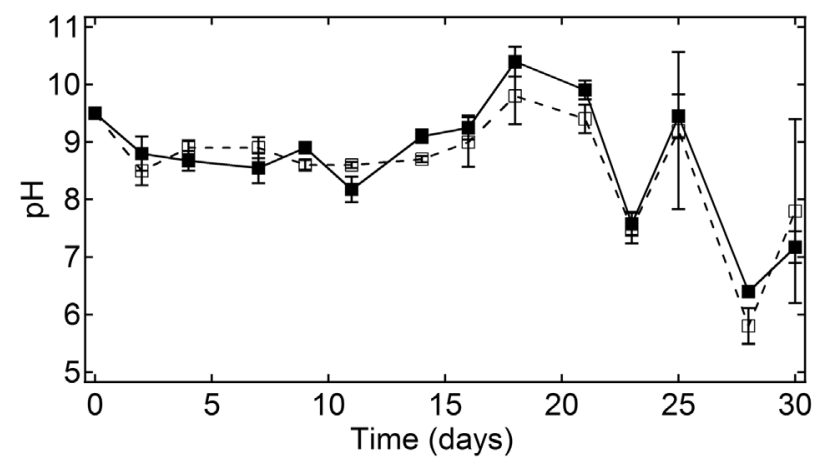

Figure 1 - Variation of $\mathrm{pH}$ in photobioreactors as a function of time in aerated (filled squares) and non-aerated (open squares) treatments. 


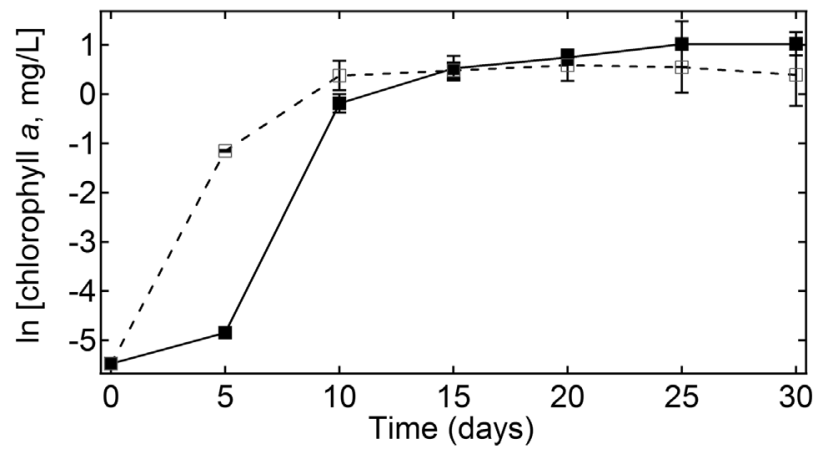

Figure 2 - Variations in the concentration of chlorophyll (mg/L) presented in natural $\log (\ln )$ in photobioreactors as a function of time in aerated (filled squares) and non-aerated (open squares) treatments. ing two genera, Pseudanabaena sp1 (35.6\%) in both treatments, and Pseudanabaena sp2 $(0.28 \%)$ and Spirulina sp $(0.71 \%)$ in the aerated treatment only. The class Euglenophyceae (Euglena sp) was detected on the $1^{\text {st }}$ experimental day in both treatments, while the classes Chrysophyceae and Bacillariophyceae (Navicula sp) occurred in the aerated treatment only and in reduced percentiles.

Figure 3 synthesizes the distribution and succession of the microalgae groups throughout the experiment, in aerated (Fig 3a) and non-aerated (Fig 3b) treatments. They show that the highest density were for the class Chlorophyceae, which was present throughout the experimental period, in both bioassays. The class Cyanophyceae was detected from the $5^{\text {th }}$ to the $15^{\text {th }}$ day in the non-aerated

Table 1 - Mean values ( \pm standard deviation) of the nutrient concentration $\left(\mu \mathrm{g} \cdot \mathrm{L}^{-1}\right)$ in the initial and end samples of the experiments (aerated and non-aerated treatments). TKN $=$ total Kjeldahl nitrogen.

\begin{tabular}{|c|c|c|c|c|c|}
\hline \multirow[t]{2}{*}{ Nutrient $(\mu \mathrm{g} / \mathrm{L})$} & \multirow[t]{2}{*}{ Initial } & \multicolumn{2}{|c|}{ Aerated } & \multicolumn{2}{|c|}{ Non-Aerated } \\
\hline & & Total value & Reduction & Total value & Reduction \\
\hline Nitrite & 23.69 & $7.53( \pm 2.23)$ & $68 \%$ & $764.03( \pm 124.5)$ & N.R.* \\
\hline Nitrate & 79.64 & $36.73( \pm 0.29)$ & $54 \%$ & $8950.67( \pm 2203.94)$ & N.R.* \\
\hline Ammonium & 13.05 & $5.86( \pm 2.36)$ & $45 \%$ & $144.98( \pm 32.45)$ & N.R.* \\
\hline TKN & 30330.00 & $2570.00( \pm 0.00)$ & $92 \%$ & $18790.00( \pm 6550.0)$ & $38 \%$ \\
\hline Total Phosphorus & 2387.10 & $1699.58( \pm 276.18)$ & $29 \%$ & $2250.58( \pm 201.17)$ & $21 \%$ \\
\hline Phosphate & 1342.90 & $78.19( \pm 17.63)$ & $94 \%$ & $1062.00( \pm 154.11)$ & $18 \%$ \\
\hline Total Dissolved Phosphorus & 1464.80 & $530.74( \pm 52.75)$ & $64 \%$ & $1196.48( \pm 137.67)$ & $6 \%$ \\
\hline
\end{tabular}

*N.R. $=$ no reduction.

Table 2 - Taxonomic composition and relative abundance (\%) of algal taxa obtained in the aerated treatment during the experimental period. Samples obtained on experimental days $1,5,10,15,20,25$ and 30 .

\begin{tabular}{|c|c|c|c|c|c|c|c|}
\hline Aerated treatment & 1 & 5 & 10 & 15 & 20 & 25 & 30 \\
\hline \multicolumn{8}{|l|}{ Chlorophyceae } \\
\hline Chlorella sp & 97.90 & 62.50 & 99.70 & 99.60 & 99.60 & 99.60 & 99.30 \\
\hline Chlamydomonas sp & - & 1.83 & 0.18 & 0.33 & 0.23 & 0.23 & 0.47 \\
\hline Desmodesmus quadricauda & - & - & - & 0.33 & 0.01 & 0.05 & 0.04 \\
\hline Desmodesmus sp & - & - & - & 0.01 & - & 0.01 & - \\
\hline Oocystis sp & - & - & - & - & 0.04 & 0.03 & 0.10 \\
\hline Scenedesmus acuminatus & - & - & - & 0.02 & 0.02 & - & 0.04 \\
\hline \multicolumn{8}{|l|}{ Cyanophyceae } \\
\hline Pseudanabaena sp1 & - & 35.80 & 0.09 & - & - & - & - \\
\hline Pseudanabaena sp2 & - & 0.28 & - & - & - & - & - \\
\hline Spirulina $\mathrm{sp}$ & - & 0.71 & - & - & - & - & - \\
\hline \multicolumn{8}{|l|}{ Chrysophyceae } \\
\hline Alga unidentified & - & - & - & 0.01 & 0.03 & 0.06 & 0.01 \\
\hline \multicolumn{8}{|l|}{ Euglenophyceae } \\
\hline Euglena sp & 2.10 & - & - & - & - & - & - \\
\hline \multicolumn{8}{|l|}{ Bacillariophyceae } \\
\hline Navicula $\mathrm{sp}$ & - & 0.01 & 0.04 & - & - & - & - \\
\hline
\end{tabular}


Table 3 - Taxonomic composition and relative abundance (\%) of algal taxa obtained in the non-aerated treatment during the experimental period. Samples obtained on days $1,5,10,15,20,25$ and 30 .

\begin{tabular}{|c|c|c|c|c|c|c|c|}
\hline Non-aerated treatment & 1 & 5 & 10 & 15 & 20 & 15 & 30 \\
\hline \multicolumn{8}{|l|}{ Chlorophyceae } \\
\hline Chlorella sp & 100.00 & 87.30 & 99.40 & 99.30 & 99.80 & 99.90 & 99.90 \\
\hline Chlamydomonas sp & - & - & 0.29 & 0.32 & 0.20 & 0.10 & 0.07 \\
\hline Desmodesmus quadricauda & - & - & - & - & - & - & 0.01 \\
\hline Oocystis sp & - & - & - & - & - & - & 0.01 \\
\hline \multicolumn{8}{|l|}{ Cyanophyceae } \\
\hline Pseudanabaena sp1 & - & 12.70 & 0.30 & 0.39 & - & - & - \\
\hline
\end{tabular}

bioassays. The classes Chrysophyceae, Bacillariophyceae and Euglenophyceae were present in trace amounts and therefore were grouped altogether within other groups. The class Euglenophyceae was observed in both treatments, while the classes Bacillariophyceae and Chrysophyceae in the aerated treatment only.

\section{Coliforms analyses}

Results obtained for the coliform group of bacteria are reported in Figure $4 \mathrm{a}$ (total coliforms) and $4 \mathrm{~b}$ (E. coli). They show that the reduction of colony forming units for both total coliforms and for E. coli occurred abruptly in the
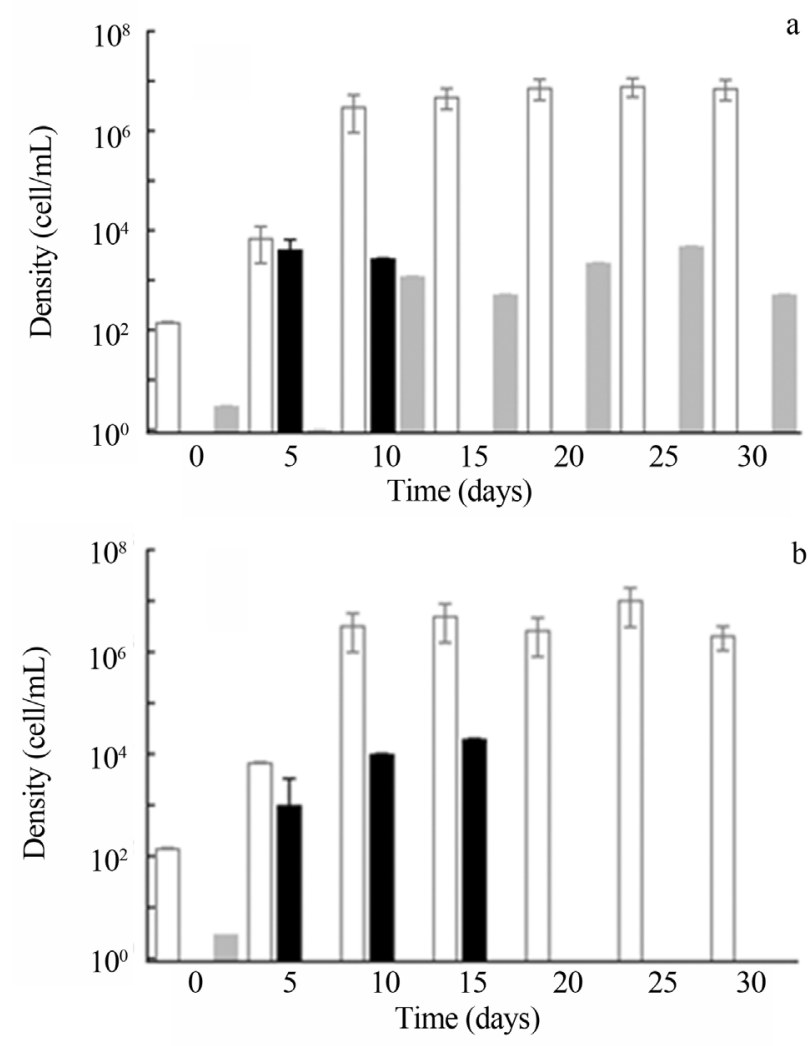

Figure 3 - Phytoplanktonic groups density (cells/mL) in the aerated (a) and non-aerated (b) treatments throughout the experimental period. White columns represent the class Chlorophyceae, the class Cyanophyceae black, and gray Other Groups (classes Chrysophyceae). first 2 days, no longer detected after the 18th day and the 11 th day for total coliforms and after the $11^{\text {th }}$ day for E. coli, regardless of the treatment.

\section{Discussion}

\section{$\mathrm{pH}$ and chlorophyll a}

The $\mathrm{pH} \sim 8.0$ in the beginning of the experiments can be attributed to the methanogenesis occurring during the anaerobic treatment. According Jeris and McCarty (1965) and Weimer and Zeikus (1978), methanogenic archaea convert $\mathrm{H}^{+}$ions and organic acids in $\mathrm{CH}_{4}, \mathrm{H}_{2} \mathrm{O}$ and $\mathrm{HCO}_{3}{ }^{-}$,
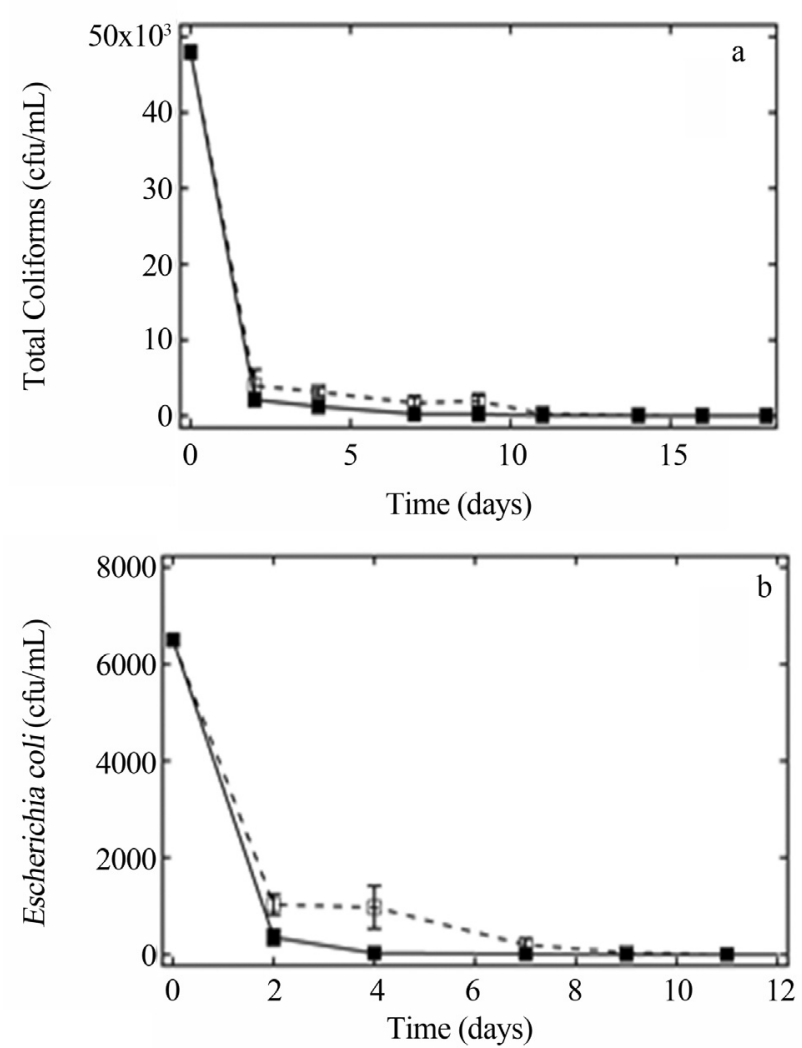

Figure 4 - Density of total coliforms (a) and Escherichia coli in aerated (filled squares) and non-aerated (open squares) treatments over the experimental period reported in colony forming units per $\mathrm{mL}(\mathrm{CFU} / \mathrm{mL})$. 
what helps maintain basic $\mathrm{pHs}$. This fact, alied to algae growth that consumes nitrate and inorganic carbon, can be responsible for the $\mathrm{pH}$ maintenance (Reynolds, 2006). The reduction of $\mathrm{pH}$ at the end of the experiment for both treatments can be a result of the decrease of microalgae growth, as detected after the $10^{\text {th }}$ experimental day and shown as the stationary growth phase in Figure 2. Besides this, bacteria degradation in the effluent, as discussed in von Sperling (1996), Arauzo et al. (2000), Bitton (2005), AmengualMorro et al. (2012) may have contributed to $\mathrm{pH}$ decrease in the treatment.

Phytoplankton growth in both aerated and non-aerated treatments, resulted in increased chlorophyll $a$ and cell density. The initial lag phase observed just for the aerated treatment also was found by Bernal et al. (2008) and Zhang et al. (2011) that lasted at least 8 days when investigating changes in the structure and dynamics of the phytoplankton community in domestic effluents from primary treatment. It is known that aeration in microalgae cultures helps create turbulence, so decreasing microalgae self-shading (Larsdotter, 2006) and furnishing the cultures with $\mathrm{CO}_{2}$, an essential nutrient for photosynthetic microalgae (Fontes et al., 1987; Becker, 1994). In the present research, we showed that although aeration was an important factor for the development of algae and the combination of algae growth, nutrient decrease and bacteria reduction, no significant difference was observed for the maximum cell density between the aerated and non-aerated treatments within 10 to 15 days of incubation.

\section{$\mathrm{N}$ and $\mathrm{P}$ concentrations}

Phosphate reduction, more intense in the aerated than in non-aerated treatment, can be associated with consumption by microalgae (Larsdotter, 2006; Boelee et al., 2011; Zhang et al., 2011). Boelee et al. (2011) showed that microalgae are effective at removing phosphate when used as tertiary biological treatment of wastewater. Several microalgae can assimilate and store $\mathrm{P}$ as polyphosphate granules inside the cells through the $\mathrm{P}$ luxurious consumption (Larsdotter, 2006), what can help in the reduction of $P$ from the effluent.

The significant $\mathrm{N}$ reduction observed in the aerated treatment in the present research has also been obtained in other investigations and can be related to the sum of processes occurring simultaneously while bubbling, e.g., nitrification, consumption of $\mathrm{NH}_{4}^{+}$by microalgae and elimination of $\mathrm{NH}_{3}-\mathrm{N}$ to the atmosphere (Mayo and Noike, 1994; Zhang et al., 2011; Ray et al., 2012). Although the non-aerated treatment had their $\mathrm{N}$ concentration decreased, the percent reduction $(\sim 38 \%)$ was much lower than the aerated $(\sim 92 \%)$. This difference can be due to different transformations of $\mathrm{N}$ in the two treatments, such as the oxidation of $\mathrm{NH}_{4}{ }^{+}$to $\mathrm{N}_{2}$ under the aerated conditions. In addition, the lower cell density detected at the end of the non-aerated treatment as compared with the aerated may have lead to $\mathrm{N}$ accumulation, which was then quantified at the end of the treatment as $\mathrm{NO}_{2}^{-}, \mathrm{NO}_{3}{ }^{-}$and $\mathrm{NH}_{4}{ }^{+}$. According to Raven (1988), Borowitzka et al. (1998) and Wood et al. (1999) aeration has the important function of system homogenization, exposure of microalgae to light and nutrients, thus enabling photosynthesis, population growth and nutrient consumption. The reduction in the concentration of nutrients ( $\mathrm{N}$ and $\mathrm{P}$ ) during the experiment shows the effectiveness and importance of tertiary treatment with microalgae to the improve the quality of the final effluent, reducing the environmental impact after its discharge into receiving water bodies.

\section{Phytoplanktonic community}

In the present study, qualitative analysis of the phytoplankton community in both treatments confirmed the presence of microalgae typical of environments with high content of organic materials and a greater diversity for the aerated in comparisom with the non-aerated treatment. This agree with other studies (Palmer, 1980; König, 1984; König et al., 2005), that showed that phytoplankton diversity in sewage effluent is influenced by factors such as organic loading, hydraulic retention time, temperature, $\mathrm{pH}$, and nutrient concentration (Hosetti and Frost, 1998; Kayombo et al., 2002; Zanotelli et al., 2002; Ahmad et al., 2005). According to Palmer $(1969 ; 1980)$ and König (1984), the composition of phytoplankton community is strongly related with the concentration of nutrients and organic materials.

The Chlorophyceae dominance in comparison with other classes obtained in the present study has been observed by Palmer (1969) and Bernal et al. (2008). Such dominance can be due to the resistance and adaptation of the Chlorophyceae for hughly eutrophic environments. In our study, the species Chlorella vulgaris dominated in all treatments, with approximately $99 \%$ over the other microalgae. Chu et al. (2009) and Bhatnagar et al. (2010), also found dominance of the genus Chlorella in sewage treatment effluents. Shanthala et al. (2009) evaluated phytoplankton diversity in stabilization ponds and obtained dominance of Chlorella sp and Scenedesmus sp; König et al. (2002) studied stabilization ponds in the state of Paraíba (Brazil) and also had low contribution of taxa other than Chlorella sp. According Salomoni (1997), organisms such as the species Chlorella vulgaris, which survive in environments rich in nutrients and organic materials exhibit adaptive features such as small size and high growth rate that enable them to dominate in such environments. It is known that the smaller the size, greater the efficiency in the absorption and assimilation of nutrients (r-strategists organisms) due to the increased surface/volume ratio. In addition, there is evidence that sodium triphosphate, a common constituent of synthetic detergent present in domestic sewage, can stimulate the growth of Chlorella vulgaris (Palmer, 1980; Granado, 2004). Another aspect that may have favored C. vulgaris in relation to other species is the 
production of chloreline, a substance that has bactericidal properties and is capable of inhibiting growth, respiration and photosynthesis of other algae, besides affecting the metabolism of other organisms (Pratt, 1944; Ryther, 1954).

The species C. vulgaris has great potential for the production of lipids, which can be converted into biodiesel, a substitute for fossil fuels (Christenson and Sims, 2011; Perez-Garcia et al., 2011). In relation to this biotechnological potential, the present study demonstrated that effluent from anaerobic sewage treatment can be used as culture media for the production of C. vulgaris, which has come to represent over $99 \%$ of all microalgae in the experiment.

The class Cyanophyceae is, in general, resistant to organic and inorganic pollution, sewage effluents and anaerobic environments with high organic loads (Ahmand et al., 2005; Komárek and Anagnostidis, 2005; Tucci et al., 2006; Escorihuela et al., 2007). However, they can be sensitive to turbidity (Havens et al., 2004), what may have accounted for the low percent contribution of the Cyanophyceae $(36 \%)$ in the present investigation. The N:P ratio can also influence the presence/absence of specific groups of phytoplankton. According Pearsall (1930) and Arauzo et al. (2000) the N:P ratio in anaerobic effluent is not favorable to Cyanophyceae. Havens et al. (2004) claim that N:P ratios $<29$ favor Cyanophyceae in detriment to other classes, which may be favored in N:P ratios $>29$ such as the Chlorophyceae. Considering the values of total $\mathrm{N}$ (30.4 mg. $\left.\mathrm{L}^{-1}\right)$ and $\mathrm{P}\left(2.4 \mathrm{mg} . \mathrm{L}^{-1}\right)$ quantified in the beginning of the experiments, the N:P ratio in the anaerobic effluent of this study was 12.7. Although lower than 29, it seemed not favorable to the Cyanophyceae. Farina (2011), studying the population dynamics of microalgae in secondary effluent from domestic aerobic treatment, found dominance of Cyanophyceae and greater variety of phytoplankton groups than observed in the present research. According to the author, this was a consequence of low N:P ratios found in effluents of aerobic wastewater treatments, a fact also observed by Ahmadi et al. (2005) and Bernal et al. (2008). The most abundant genus of Cyanobacteria in this work, Pseudanabaena sp, was observed in both aerated and non-aerated treatments. This genus is common in eutrophic environments, and dominant in effluent from pulp and paper industry (Kirkwood et al., 2003; Wehr and Sheath, 2003; Komárek and Anagnostidis, 2005).

In the aerated treatment, the classes Bacillariophyceae and Chrysophyceae were present in low proportion compared with the Chlorophyceae, what is in agreement with other works about biodiversity in effluents (Mendes et al., 1995; Sukias et al., 2001; Tharavathi and Hosetti, 2003; Bernal et al., 2008).

As reported by Roche (1995), individuals of the class Euglenophyceae are scarce in effluents and the mixotrophic genus Euglena sp (Pearson, 1986) is sensitive to variation in environmental conditions, what may have accounted for its presence just on the 1st day of sampling, both in the aerated and non-aerated treatments.

\section{Coliforms analyses}

The reduction of total coliforms and E. coli, and their absence after $\sim 10$ days of incubation confirms other literature studies (Pearson et al., 1987; Dixo et al., 1995; Hammouda et al., 1995; Tangeby et al., 1996; Davies-Colley et al., 1997; Kiso et al., 2005; Bernal et al., 2008) that have shown reduction of these organisms in effluent treatments employing microalgae. Hanajima et al. (2011) reported that air bubbling can reduce populations of fecal coliforms. The initial presence and reduction of colony forming units of coliform and $E$. coli in both aerated and non-aerated treatments confirm that using microalgar as tertiary treatment improves the quality of the sewage effluent and can be adopted as routine procedure in sewage treatment plants before discarding the effluent, making the microalgal treatment sustainable and efficient in the reduction of coliforms.

However, most literature that report on $E$. coli reduction, shows it is less intense than what we obtained in the present research, a reduction of $4 \operatorname{logs}$ times $(99.9 \%$ of the bacteria were reduced) for $E$. coli was detected, whereas according Kassab et al. (2010) anaerobic treatment can be responsible for a $1 \log$ reduction of E. coli only. According to literature, the significant reduction of coliform bacteria and E. coli we obtained can be attributed to the $\mathrm{pH}$ variation in the effluent as result of algae photosynthesis in the light and respiration in the dark (natural light cycle). In fact, our results showed significant variation of $\mathrm{pH}$ when comparing $\mathrm{pHs}$ for each experimental day. This is confirmed by the experiments of König et al. (1999) and Amengual-Morro et al. (2012), who showed that the microlagae photosynthetic activity in sewage treatment effluents overcomes bacteria respiration during daytime, leading to an imbalance in $\mathrm{pH}$ between day and night. This leads to the inactivation of coliform and other bacteria forms. According Metcalf and Eddy (2003), there are bacteria that do not support $\mathrm{pH}$ above 9.5 or below 4.0 , with the optimal range of $\mathrm{pH}$ between 6.5 and 7.5. In addition, the low depth of the bioreactors favored light penetration, which may have contributed to bacteria reduction (Pearson et al., 1987; von Sperling, 1996; Cavalcanti et al., 2001; Cordero et al., 2010).

We showed that the effluent from an anaerobic sewage treatment (constituted by domestic and aircraft maintenance operation) supported the growth of native Chlorella vulgaris with a productivity $2.4 \times 10^{5}$ cels. $\mathrm{mL}^{-1}$. day ${ }^{-1}$ better than did the same effluent, but in non-aerated conditions. The growth of $C$. vulgaris in such aerated effluent improved its quality, reducing in $99 \%$ the colony forming units of total coliform bacteria and Escherichia coli, at the same time that the concentration of nitrogen and phosphorus were reduced. This study confirmed the sustainable character of using microaalgae for tertiary treatments of wastewater: it reduced $\mathrm{N}$ and $\mathrm{P}$ and pathogenic bacteria, so 
decreasing the potential impact the discharge of secondary effluent can cause the receiving water body, at the same time that serves for the production of microalgal biomass.

\section{Acknowledgments}

The authors thank Profa. Dra. Odete Rocha from Universidade Federal de São Carlos for making available the microscopes and other laboratory facilities, and Dra. Celia Leite Sant'Anna, from Institute of Botany (São Paulo, Brazil), for identification of Chlorella vulgaris species. We also thank the Brazilian agencies FAPESP (Proc. No. 2008/03487-0) and CNPq (Proc. No. 314361/2009; 302837/2012-4) for financial support.

\section{References}

Ahmadi A, Riahi H, Noori M (2005) Studies of the effects of environmental factors on the seasonal change of phytoplankton population in municipal wastewater stabilization ponds. Toxicol Environ Chem 87:543-550.

Aksu Z (1998) Biosorption of Heavy Metals by Microalgae in Batch and Continuos Systems. In: Wong YS, Tam NFY (eds) Wastewater Treatment with Algae. Springer-Verlag, Berlin, pp 37-54.

Amengual-Morro C, Niell GM, Martínez-Taberner A (2012) Phytoplankton as bioindicator for waste stabilization ponds. J Environ Manag 95:571-576.

Anagnostidis K, Komárek J (1989) Modern approach to the classification system of cyanophytes, 4 - Nostocales. Archiv für Hydrob 80:237-472.

APHA (2005) Standard Methods for the Examination of Water and Wastewater. American Public Health Association, Washington, DC, $541 \mathrm{pp}$.

Arauzo M, Colmenarejo MF, Martínez E et al. (2000) The role of algae in a deep wastewater self regeneration pond. Wat Res 34:3666-3674.

Becker EW (1994) Microalgae, Biotechnology and Microbiology. Cambridge University Press, Cambridge, 304 pp.

Bernal CC, Vázquez G, Quintal IB et al. (2008) Microalgal dynamics in batch reactors for municipal wastewater treatment containing dairy sewage water. Wat Air Soil Pol 190:259270.

Bhatnagar A, Bhatnagar M, Chinnasamy S (2010) Chlorella minutissima - A promising fuel alga for cultivation in municipal wastewaters. Ap Bioch Biotech 161:523-536.

Bicudo CEM, Menezes M (2005) Gêneros de Algas de Águas Continentais do Brasil. Chave para Identificação e Descrições. Rima, São Paulo, 502 pp.

Bitton G (2005) Wastewater Microbiology. Wiley-Liss, Hoboken, 765 pp.

Boelee NC, Temmink H, Janssen M et al. (2011) Nitrogen and phosphorus removal from municipal wastewater effluent using microalgal biofilms. Wat Res 45:5925-5933.

Borowitzka MA (1998) Limits to growth. In: YS Wong \& NFY Tam (eds) Wastewater treatment with algae. SpringerVerlag, Berlin, pp 203-226.

Cavalcanti PFF, Mayer MGR, Moreira EAM et al. (2001) Lagoas de polimento para o pós-tratamento de esgotos digeridos Parte 2 - Remoção de Patógenos. In: C Chernicharo (ed)
Pós-Tratamento de Efluentes de Reatores Anaeróbios. Coletânea de Trabalhos Técnicos, Belo Horizonte, pp 69-78.

Cho S, Luong TT, Lee D et al. (2011) Reuse of effluent water from municipal wastewater treatment plant in microalgae cultivation for biofuel production. Biores Tech 102:86398645.

Christenson L, Sims R (2011) Production and harvesting of microalgae for wastewater treatment, biofuels and bioproducts. Biotech Adv 2:686-702.

Chu WL, See YC, Phang SM (2009) Use of immobilized Chlorella vulgaris for the removal of colour from textile dyes. $\mathrm{J}$ Ap Phyc 21:641-648.

Cordero A, García M, Herradora M et al. (2010) Bacteriological characterization of wastewater samples obtained from primary treatment system on a small scale swine farm. Biores Tech 101:2938-2944.

Davies-Colley RJ, Donnison AM, Speed DJ (1997) Sunlight wavelengths in faecal indicator microorganisms in waste stabilization ponds. Wat Sc Tech 35:219-225.

de Bashan LE, Hernandez JP, Morey T et al. (2004) Microalgae growth-promoting bacteria as "helpers" for microalgae: a novel approach for removing ammonium and phosphorus from municipal wastewater. Wat Res 38:466-474.

de La Noüe J, Laliberté G, Proulx D (1992) Algae and wastewater. J Ap Phyc 4:247-254.

de Paul M (2002) Caracterización biológica de lagunas de estabilización (Jujuy) con diferentes tiempos de retención hidráulico. In: International development and appropriate technologies for sewage management and environment. Buenos Aires, 14 pp.

Dixo NGH, Gambrill MP, Catunda PFC et al. (1995) Removal of pathogenic organism from the effluent of an upflow. Wat Sc Tech 31: 275-284.

Escorihuela A, Núñez M, Rosales N et al. (2007) Microalgas presentes em uma laguna para pulimento de efluentes de uma planta de tratamento de águas residuales urbanas. Facultad de Agronomia Universidad Zulia 24:225-230.

Farina VOA (2011) Dinâmica Populacional de Microalgas em Efluente Secundário de ETE (tratamento aeróbio) com diferentes razões N:P. Trabalho de Conclusão de Curso. Universidade Estadual Paulista, Assis, 48 pp.

Fontes AG, Vargas MA, Moreno J et al. (1987) Factors affecting the production of biomass by a nitrogen-fixing blue-green alga in outdoor culture. Biomass 13:33-43.

Granado DC (2004) Variações nictemerais e sazonais na estrutura da comunidade fitoplanctônica num sistema de lagoas de estabilização (Novo Horizonte, SP). São Paulo, Brasil. Dissertação, Universidade de São Paulo, 130 pp.

Hammouda O, Gaber A, Abdel-Raouf N (1995) Microalgae and wastewater treatment. Ecotox Environ Saf 31:205-210.

Hammer Ø, Harper DAT, Ryan PD (2001) PAST: Paleontological statistics software package for education and data analysis. Palaeont Electr 4:9.

Hanajima D, Fukumoto Y, Yasuda T et al. (2011) Bacterial community dynamics in aerated cow manure slurry at different aeration intensities. J Ap Microb 111:1461-1425.

Havens KE, James RT, East TL et al. (2004) N:P ratios, light limitation, and cyanobacterial dominance in a subtropical lake impacted by non-point source nutrient pollution. Environ Pol 122:379-390. 
Hoffmann JP (1998) Wastewater treatment with suspended and nonsuspended algae. J Phyc 34:757-753.

Hosetti B, Frost S (1998) A review of the control of biological water treatment in stabilization ponds. Crit Rev Environ Sc Tech 28:193-218.

Jeris JS, McCarty PC (1965) Biochemistry of methane fermentation using ${ }^{14} \mathrm{C}$ tracers. J WPCF 37:178-192.

Kayombo S, Mbwette TSA, Mayo AW et al. (2002) Diurnal cycles of variation of physical-chemical parameters in waste stabilization ponds, Ecol Eng 18:287-291.

Kassab G, Halalsheh M, Klapwijk A et al. (2010) Sequencial anaerobic-aerobic treatment for domestic wastewater - A review. Biores Tech 101:3299-3310.

Kirkwood AE, Nalewajko C, Fulthorpe RR (2003) Physiological characteristics of cyanobacteria in pulp and paper wastetreatment systems. J Ap Phyc 15:325-335.

Kiso Y, Jung YJ, Park MS et al. (2005) Coupling of sequencing batch reactor and mesh filtration: operacional parameters and wastewater treatment performance. Wat Res 39:48874898.

Klausmeier CA, Litchman E, Daufresne T et al. (2004) Optimal nitrogen-to-phosphorus stoichiometry of phytoplankton. Nat 429:171-174.

Komárek J, Fott B (1983) Das phytoplankton des Süßwasser. Systematik und Biologie. Stuttgart, 543 pp.

Komárek J, Anagnostidis K (1999) Chrococcales. In: J Gerloff, H. Heynig, D. Mollenhauer (eds) Süßwasserflora von Mitteleuropa Ettl. Stuttgard, 548 pp.

Komárek J, Anagnostidis K (2005) Oscillatoriales. In B. Büdel, G. Gartner, L. Krienitz, M. Schagel (eds) Süßwasserflora von Mitteleuropa, $759 \mathrm{pp}$.

König A (1984) Ecophysiological studies on some algae and bacteria of waste stabilization ponds. $\mathrm{PhD}$ Thesis, University of Liverpool, Liverpool, 195 pp.

König A, Souza MSM, Costa NAF et al. (1999) Variação nictemeral da qualidade do efluente final de uma lagoa facultativa secundária e a influência das algas. XX Congresso Brasileiro de Engenharia Sanitária e Ambiental, Rio de Janeiro, pp 1-10.

König A, Ceballos BSO, Almeida MVA (2002) Observações sobre a população algal em efluentes de lagoas de estabilização em escala real no estado da Paraíba. XXVIII Congresso Internacional de Engenharia Sanitária y Ambiental, Cancun, pp 1-6.

Larsdotter K (2006) Wastewater treatment with microalgae - a literature review. VATTEN 62:31-38.

Lloyd BJ, Leither AR, Vorkas CA et al. (2003) Under-performance and rehabilitation strategy for waste stabilization ponds in Mexico. Wat Sc Tech 48:35-43.

Mara D, Pearson H (1998) Lagoon technology international: Design manual for waste stabilization ponds in Mediterranean countries. Leeds, England.

Mayo AW, Noike T (1994) Effect of Glucose Loading on the Growth Behavior of Chlorella vulgaris and Heterotrophic Bacteria in Mixed Culture. Wat Res 28:1001-1008.

Meiring P, Rose P, Shipin O (1994) Algal Aid Puts a Sparkle on Effluent. WQI, $30 \mathrm{pp}$.

Mendes B, Lapa N, Morais J et al. (1995) Statistical relationships between biological populations and organic matter in a waste stabilization pond system (WPS). III IAWQ Interna- tional specialist conference and workshop waste stabilization ponds technology and applications. London.

Metcalf \& Eddy, Inc (2003) Wastewater Engineering, Treatment, Disposal and Reuse. McGraw-Hill Science, India, 1848 pp.

Olguín EJ (2003) Phycoremediation: key issues for cost-effective nutrient removal processes. Biotech Adv 22:81-91.

Oswald WJ (1988a) Large scale culture systems: engineering aspects. In: LJ Borowitzka (ed) Microalgal Biotechnology. Cambridge University Press, Cambridge, pp 205-218.

Oswald WJ (1988b) Microalgae and wastewater treatment. In: LJ Borowitzka (ed) Microalgal Biotechnology. Cambridge University Press, Cambridge, pp 153-163.

Palmer CM (1969) Composite Rating of Algae Tolerating Organic Pollution. J Phyc 5:78-82.

Palmer CM (1980) The identification, significance, and control of algae in water supplies and in polluted water. In: Algae and Water Pollution. Castle House Publications Lrd, UK, $140 \mathrm{pp}$.

Pearsall WH (1930) Phytoplankton of English lakes, I. The proportion in the water of some dissolved substances of biological importance. J Ecol 18:306-320.

Pearson HW (1986) Estimation of chlorophyll- $a$ as a measure of algae biomass in waste stabilization ponds. Pan American Center for Sanitary Engineering and Environment Sciences, Lima, 3-7 March.

Pearson HW, Mara DD, Mills SW et al. (1987) Physico-chemical parameters influencing faecal bacterial survival in waste stabilization ponds. Wat Sc Tech 19:145-152.

Perez-Garcia O, Escalante FME, de-Bashan LE et al. (2011) Heterotrophic cultures of microalgae: metabolism and potential products. Wat Res 45:11-36.

Pratt R (1944) Chlorellin, an antibacterial substance from Chlorella. Scien 99:351-352.

Rangeby M, Johansson P, Pernup M (1996) Removal of fecal coliforms in a wastewater stabilization pond. Wat Sci Technol 34:149-157.

Raven JA (1988) Limits to growth, in Micro-algal biotechnology. In: MA Borowitzka, LJ Borowitzka (eds) Cambridge University Press, Cambridge, pp 331-356.

Ray R, Henshaw P, Biswas N (2012) Effects of reduced aeration in a biological aerated filter. Canadian J Civ Eng 39:432438.

Reynolds C (2006) The ecology of freshwater phytoplankton. Cambridge University Press, Cambridge, $551 \mathrm{pp}$.

Roche KF (1995) Growth potential of Daphnia magna Straus in the water of dairy waste stabilization ponds. Wat Res 32:1352-1328.

Ryther JH (1954) Inhibitory effects of phytoplankton upon the feeding of Daphnia magna with reference to growth, reproduction and survival. Ecol 35:522-533.

Salamoni SE (1997) Aspectos da limnologia e população costeiras Marcelino, Peixoto e Pinguela (Osório, RS): uma abordagem baseada no fitoplâncton. Porto Alegre, Brasil. Dissertação, Universidade Federal do Rio Grande do Sul, Porto Alegre, 145 pp.

Shanthala M, Hosmani SP, Hosetti BB (2009) Diversity of phytoplankton in a waste stabilization pond at Shimoga Town, Karnataka State, India. Environ Mon Asses 151:437-443.

Sukias JPS, Tanner CC, Davies-Colley RJ et al. (2001) Algal abundance, organic matter and physic-chemical characteris- 
tics of dairy farm facultative ponds: implications for treatment performance. New Zel J Agric Res 44:279-296.

Tarlan E, Dilek FB, Yetis U (2002) Effectiveness of algae in the treatment of a wood-based pulp and paper industry wastewater. Biores Tech 8:1-5.

Tharavathi NC, Hosetti BB (2003) Biodiversity of algae and protozoa in a natural waste stabilization pond: a field study. J Environ Biol 24:193-199.

Tucci A, Sant'Anna CL, Gentil RG et al. (2006) Fitoplâncton do Lago das Garças, São Paulo, Brasil: um reservatório urbano eutrófico. Hoehnea 33:147-175.

Utermöhl H (1958) Zur vervollkommnung der quantitative phytoplankton-methodik. Mitt Internat Ver Limnol 9:1-38.

Villaverde S (2004) Recent developments on biological nutrient removal processes for wastewater treatment. Rev Environ Sc Biotech 3:171-183.

von Sperling M (1996) Princípio do Tratamento Biológico de Águas Residuárias - Lagoas de Estabilização. DESAUFMG, Belo Horizonte, 196 pp.

Weimer PJ, Zeikus JG (1978) Acetate metabolism in Methanosarcina barceri. Arq Microb 119:175-182.

Wehr JD, Sheath RG (2003) Freshwater Algae of North America: Ecology and Classification. Academic Press, Amsterdam, $918 \mathrm{pp}$.
Wetzel RG, Likens GE (1991) Limnological analysis. W.B. Sunders Company, Philadelphia, $391 \mathrm{pp}$.

Wiesmann U, Choi IS, Dombrowski EM (2007) Fundamentals of biological wastewater treatment. Weinheim, Wiley, $409 \mathrm{pp}$.

Wood BJB, Grimson PHK, German JB et al. (1999) Photoheterotrophy in the production of phytoplankton organisms. J Biotech 70:175-183.

Zanetti F, de Luca GND, Sacchetti R (2006) Microbe removal in secondary effluent by filtration. An Microb 56:313-317.

Zanotelli C, Peres A, Perdomo C et al. (2002) Identificação de algas e clorofila $a$ em lagoas facultativas no tratamento de dejetos suínos. In: Environmental Challenges of the Globalization, Vitoria.

Zhang M, Lawlor PG, Wu G et al. (2011) Partial nitrification and nutrient removal in intermittently aerated sequencing batch reactors treating separated digestate liquid after anaerobic digestion of pig manure. Biop Bios Eng 34:1049-1056.

Associate Editor: Lara Durães Sette

All the content of the journal, except where otherwise noted, is licensed under a Creative Commons License CC BY-NC. 